\title{
A REVIEW INVESTIGATING AGRARIAN FEMALE ENTREPRENEURSHIP IN THE REPUBLIC OF SERBIA
}

\author{
Goran Maksimovićc, Slavica Otović2 ${ }^{2}$ Dunja Demirović ${ }^{3}$, Tatjana Vermezovic ${ }^{4}$
}

\begin{abstract}
Present research has found the link between economic development, gender equality and rural development of particular areas. Female agrarian entrepreneurship leaning on multifunctional agriculture and agribusiness, can create favorable work climate in the whole region. Comparative analysis of female agrarian entrepreneurship of some populated places in north and south of Serbia gives information that can help in creating independent regional developmental politics. Experiences, attitudes, suggestions and recommendations acquired from polled women entrepreneurs give valuable and hardly attainable data to the other women living in rural areas and planning on starting their own businesses.
\end{abstract}

Key words: female agrarian entrepreneurship, gender equality, agribusiness, village, economic development, rural development

JEL: $M 21, Q 13$.

\section{Introduction}

Entrepreneurship represents a proactive and innovative economic activity carried out by an individual or a group of individuals connected by a binding contract. The European Union (EU) gives a strong support to the idea of the agrarian entrepreneurship, especially to the agrarian entrepreneurship led by women. Supporting this concept provides sustainability of rural development as the second bearer of the agrarian politics.

1 Maksimović Goran Ph.D., Assistant Professor, University of Prishtina, Faculty of Agriculture, 38219 Leshak, Phone: +381 2888 261, E-mail: goran.maksimovic@pr.ac.rs

2 Otović Slavica M.Sc., Public relations manager, General hospital Vrbas, Dr M. Čekica Street no. 4, 21460 Vrbas, Phone: +381 64802 3215, E-mail: slavicaotovic1@gmail.com

3 Demirović Dunja M.Sc., PhD student, University of Novi Sad, Faculty of Sciences, Department of Geography, Tourism and Hotel Management, Dositeja Obradovića Square no. 3, Novi Sad, Phone: +381 642686 290, E-mail: demirovic.dunja2@gmail.com

4 Vermezović Tatjana BA, masters student, University of Novi Sad, Faculty of Philosophy, Psychology Department, Novi Sad, Phone: +381 63521 715, E-mail: tatjana.vermezovic@gmail.com

EP 2016 (63) 1 (29-46) 
Women entrepreneurs have made substantial gains in terms of business education, corporate experience, and technical expertise. Women seek entrepreneurship for flexibility and autonomy, satisfaction and personal growth, and income and prestige (Winn, 2005; Winn, 2004). Too often, entrepreneurial efforts by women have gone unnoticed, and their contributions have been underappreciated usually because women's business ventures, particularly those in less developed countries, function more in the informal rather than formal economy (Datta et al., 2012).

In the Republic of Serbia, and especially in rural areas, women are not involved in rural agrarian activities. This is mainly due to the fact the dominant impact of tradition and the socio-economic outcome of gender differences are amplified by the educational structure, and differences in knowledge, skills and society's approach to education lead to an insufficient ability for the significant overcoming of gender differences. Many women are paid unofficially for their work - these types of payments are not recorded in officially gathered statistics. Also, some women who either want to work or wish to increase their hours are not officially registered as unemployed and therefore do not in appear as data in statistical analysis. This stands for women in general, but likely is more pronounced is rural areas through 'hidden' unemployment and seasonal work (Bock, 2010)

Some studies from the past decade clearly indicate a direct relationship between the level of gender equality that a society has reached and the level of sustainable economic and social development and long term prosperity (according to EU progress, 2015). Revitalizing the village economy is one of the basic demands for villages which have their rural status threatened either by becoming too large (and becoming a town), or by becoming engulfed in urban sprawl from a nearby town or city, or by annulling its own vitality (Čikić et al., 2011; Samardžija et al., 2005).

The key to starting the inner mechanism of development must be based upon gender sensitive research and analysis, which in turn are based on multiple statistical methods and gather data about entrepreneurship on the international level and Republic of Serbia.

\section{Methods, Goal and Purpose of the Research}

The comparative analysis of female agrarian entrepreneurship of certain populated places in the North and the South of Serbia is based on the market research carried out by polling and questionnaires regarding the proportion of female agrarian entrepreneurship with special attention to agri-business, women in villages and rural development.

The questionnaire comprises of 5 parts: personal and family data of the woman entrepreneur, personal attitudes, data about the entrepreneur activities they have done so far, relationship with the environment, advice and suggestions to future women entrepreneurs. It was distributed in electronic form by email, personally on paper and/ or by help of the society of women entrepreneurs.

The research was carried out between 2014 and 2015 with the goal of reaching a representative sample of questioned women divided between 75 participants from the 
North and 75 participants from the South. The sample was comprised from the database of the agency of agrarian registry, the institute for gender quality of Vojvodina, the University of Kosovska Mitrovica, several societies of women entrepreneurs selected based on consultation with the Chamber of commerce and industry in Serbia, and Regional chambers of commerce.

The aim of this research is to learn about the profile of women entrepreneurs in rural areas through gathering and analyzing current empirical data alongside statistical data about socio-demographic features, ways of conducting business, and the gender based impact of the environment.

The purpose of this work is to detect basic motivators and obstacles for starting a business as a foundation for proactive action and strengthening female entrepreneurship through recommendations to amenable institutions to create specific measures.

Results of the research will serve generally as a confirmation or denial of the presented hypothesis; that there is an insufficient percent of female representation in agribusiness in rural areas, due to conflict relation between innovative spirit and patriarchic pattern of thinking and lack of communication with potential barriers of useful information.

The comparative analysis of female agrarian entrepreneurship from certain areas of the North and the South of Serbia will enable the observation of similarities and differences which can serve in further specification and creation of developmental politics in rural areas.

\section{Rural Development and Agribusiness}

According to traditionally collected figures, rural areas in Serbia comprise $70 \%$ of the territory but just $43 \%$ of the total population (Cvijanović, 2012). Regional development is conditioned by the availability and quality of agrarian land, the level of infrastructure development, formal and informal institutions, organizations, societies, as well as demographic features of the population of a certain area, social capital and level of awareness about entrepreneurial activity.

In the last half century, the centralistic developmental concept of industrialization has been applied in Serbia which has led to a polarization in which socio-economic development has been saved for the city (urban areas) and left villages (rural areas) as the only dimension of life and work agriculture has left. (Pejanović et al., 2011).

The idea of agrarian entrepreneurship starting being supported more heavily during the 1990s in the European Union according to Pejanović, 2013, and in the last several years it has been recognized as a possible solution for unemployment in the Republic of Serbia. Agrarian entrepreneurship is based on new proactive European concepts of multifunctional agriculture as well as limited production on private agrarian land which consists of all the possibilities for economic actions by individuals within the rural economy (Njegovan, 2001).

Likewise, it is crucial to affirm the entrepreneurial approach to agribusiness because of 
the prevalence of an oversimplified belief among agriculturists, tradesmen, scientists and experts. This belief is: if we have a market, we don't need any planning (Njegovan, 2002). Without a clearly specified plan about what to produce, how to produce it and whom for (which is founded on the law of offer and demand), the entrepreneurial way of business does not exist. Even if the state (Vlahović, 2013) influences an increase in the volume of agricultural producing through adequate measures of agricultural politics, which are in the function of satisfying the local market, it still fails to encompass the entrepreneurial spirit. It is not sustainable to produce random amounts of products and to produce them arbitrarily, without leaning on science, profession and certain groups of consumers (Đurašević, 2009).

Creating an operative and efficient commerce society or agricultural husbandry able to deliver demanded product implies being familiar with possible financing resources, and having marketing and management skills (modified according to Jones, 2004). Similarly (Van Praag et al., 2004) empirical results show that the level of education has the positive effect on quality of entrepreneurial execution (Kuper et al., 1994; Van Der Sluis et al., 2003; Van Der Sluiset et al., 2004). It is vital to position the role of local actors in creating and implementing measures for the realization of strategies for sustainable rural development, especially through the processes of popularization, introductions to relevant connections and entrepreneurial integration (Đekić, 2011).

The sustainability of rural development, according to the new concept, is not only represented by preserving the quality of natural resources and biodiversity, but also in saving social and cultural diversity as a foundation of planetary survival (Pejanović, 2013) through the aspects of continuous education, availability of useful information, development of entrepreneurial way of thinking and the active inclusion of the female population.

\section{Comparative analysis of the female agrarian entrepreneurship of certain populated places in the north and south of Serbia}

The research sample (150) was comprised of two sub-samples: 75 women from the north (the Autonomous Province of Vojvodina) and 75 women from the south of Serbia (the Autonomous Province of Kosovo). All of the women from the sample are owners of agrarian husbandry, are engaged in some sort of entrepreneurial activity, and are the owners of an entrepreneurial store or are a part of the managerial structure of a firm.

In both sub-samples there was an equal portion of women falling under the age categories from 35 to 49 years and from 60 to 64 years old. Furthermore, some differences in percentages were noted in the age categories of 19 to 24 years, which contained more participants from the south, and also in the age group of $65+$ which consisted only of participants from the south.

$10(13.33 \%)$ of the participants from the southern sub-sample have stated that their educational level is that of elementary school diploma or below, while there were no such cases noted in the northern sub-sample $(0(0 \%))$ and there is a somewhat larger 
number of women from the north who had finished high school. It is notable that there is almost the same portion in the both sub-samples that have higher and high education levels (north $31(41.33 \%)$, south $33(44 \%)$ ). Therefore, the conclusion can be drawn that the level of education is a strong positive relationship with the creation of a profitable business idea, entrepreneurial activity and the emancipation of women.

Additional knowledge and/or skills are noted among both subgroups of women, but there are some differences to their extent and direction. Data analysis shows that women from the south are somewhat more familiar with traditional skills which implie modern application of craft and technical knowledge through art and through implementation in distinctive product design.

Taking the sample as a whole, most of the participants live in a household which has three or four family members (north 44 (58.6\%), south $31(41.33 \%)$, meaning that the structure of the household is mainly consisting of married couples with one or more underage children (north 23 - 30,67\%, south 25 - 3.33\%). Furthermore, a large portion of the sample consists of expanded families (north 15 (20.00\%), south 17 (22.67\%)).

With regard to decisions made in respect of the distribution of the family budget, women entrepreneurs tend to make it jointly with their family members (north 46 (61. $33 \%)$, south $42(56 \%)$ ) or on their own (north $21(28 \%)$, south $21(28 \%))$. Notably, in the southern sub-sample $12(16 \%)$ women said that their husband, partner or a family member is making money-related decisions, while in the northern sub-sample only 3 $(4 \%)$ women handed these decisions to someone else.

Table 1. Ways of doing house chores and taking care of other family members

\begin{tabular}{|c|c|c|c|c|c|c|c|c|c|c|}
\hline \multirow{2}{*}{\multicolumn{2}{|c|}{$\begin{array}{c}\text { Type of choirs } \\
\text { North }\end{array}$}} & \multicolumn{2}{|c|}{ Participant } & \multicolumn{3}{|c|}{$\begin{array}{l}\text { Other woman in the } \\
\text { household-maid }\end{array}$} & \multicolumn{2}{|c|}{$\begin{array}{l}\text { Husband/ } \\
\text { Partner }\end{array}$} & \multicolumn{2}{|c|}{$\begin{array}{c}\text { Together with } \\
\text { husband/partner }\end{array}$} \\
\hline & & South & North & \multicolumn{2}{|c|}{ South } & North & South & North & South & \\
\hline \multicolumn{2}{|l|}{ Cooking } & $\begin{array}{c}54 \\
(72 \%) \\
\end{array}$ & \begin{tabular}{|c|}
57 \\
$(76 \%)$ \\
\end{tabular} & \begin{tabular}{|c|}
10 \\
$(13 \%)$ \\
\end{tabular} & \multicolumn{2}{|c|}{$\begin{array}{c}7 \\
(9 \%)\end{array}$} & $\begin{array}{c}2 \\
(3 \%) \\
\end{array}$ & $\begin{array}{c}6 \\
(8 \%) \\
\end{array}$ & $\begin{array}{c}15 \\
(20 \%) \\
\end{array}$ & $\begin{array}{c}5 \\
(7 \%) \\
\end{array}$ \\
\hline \multicolumn{2}{|c|}{ Dish washing } & $\begin{array}{c}50 \\
(67 \%) \\
\end{array}$ & $\begin{array}{c}47 \\
(63 \%) \\
\end{array}$ & \begin{tabular}{|c|}
10 \\
$(13 \%)$
\end{tabular} & \multicolumn{2}{|c|}{$\begin{array}{c}9 \\
(12 \%)\end{array}$} & $\begin{array}{c}0 \\
(0 \%) \\
\end{array}$ & $\begin{array}{c}5 \\
(7 \%) \\
\end{array}$ & $\begin{array}{c}13 \\
(17 \%) \\
\end{array}$ & $\begin{array}{c}14 \\
(19 \%) \\
\end{array}$ \\
\hline $\begin{array}{l}\text { Laundry } \\
\text { washing }\end{array}$ & $\begin{array}{c}59 \\
(79 \%) \\
\end{array}$ & $\begin{array}{c}56 \\
(75 \%) \\
\end{array}$ & $\begin{array}{c}8 \\
(11 \%) \\
\end{array}$ & \multicolumn{2}{|c|}{$\begin{array}{c}8 \\
(11 \%)\end{array}$} & $\begin{array}{c}1 \\
(1 \%)\end{array}$ & $\begin{array}{c}2 \\
(3 \%) \\
\end{array}$ & $\begin{array}{c}7 \\
(9, \%) \\
\end{array}$ & $\begin{array}{c}9 \\
(12 \%) \\
\end{array}$ & \\
\hline Ironing & $\begin{array}{c}60 \\
(80 \%) \\
\end{array}$ & $\begin{array}{c}52 \\
(69 \%) \\
\end{array}$ & $\begin{array}{c}9 \\
(12 \%) \\
\end{array}$ & \multicolumn{2}{|c|}{$\begin{array}{c}5 \\
(7 \%) \\
\end{array}$} & $\begin{array}{c}1 \\
(1 \%) \\
\end{array}$ & $\begin{array}{c}3 \\
(4 \%) \\
\end{array}$ & $\begin{array}{c}5 \\
(7 \%) \\
\end{array}$ & $\begin{array}{c}15 \\
(20 \%) \\
\end{array}$ & \\
\hline Cleaning & $\begin{array}{c}47 \\
(63 \%)\end{array}$ & $\begin{array}{c}50 \\
(67 \%)\end{array}$ & $\begin{array}{c}9 \\
(12 \%) \\
\end{array}$ & \multicolumn{2}{|c|}{$\begin{array}{c}7 \\
(9 \%) \\
\end{array}$} & $\begin{array}{c}0 \\
(0 \%)\end{array}$ & $\begin{array}{c}2 \\
(3 \%)\end{array}$ & $\begin{array}{c}21 \\
(28 \%)\end{array}$ & $\begin{array}{c}11 \\
(15 \%)\end{array}$ & \\
\hline \multicolumn{10}{|c|}{ Participants living in families with children, expanded family or with relatives: } & \\
\hline $\begin{array}{l}\text { Taking } \\
\text { care of } \\
\text { small kids } \\
(0-6 \text { y. })\end{array}$ & $\begin{array}{c}7 \\
(9 \%)\end{array}$ & $\begin{array}{c}9 \\
(12 \%)\end{array}$ & \multicolumn{2}{|c|}{$\begin{array}{c}0 \\
(0 \%)\end{array}$} & $\begin{array}{c}0 \\
(0 \%)\end{array}$ & $\begin{array}{c}7 \\
(9 \%)\end{array}$ & $\begin{array}{c}1 \\
(1 \%)\end{array}$ & $\begin{array}{c}15 \\
(20 \%)\end{array}$ & $\begin{array}{c}3 \\
(4 \%)\end{array}$ & \\
\hline
\end{tabular}




\begin{tabular}{|l|c|c|c|c|c|c|c|c|c|}
\hline $\begin{array}{l}\text { Taking } \\
\text { care of } \\
\text { school } \\
\text { duties }\end{array}$ & $\begin{array}{c}15 \\
(20 \%)\end{array}$ & $\begin{array}{c}15 \\
(20 \%)\end{array}$ & $\begin{array}{c}0 \\
(0 \%)\end{array}$ & $\begin{array}{c}0 \\
(0 \%)\end{array}$ & $\begin{array}{c}1 \\
(1 \%)\end{array}$ & $\begin{array}{c}3 \\
(4 \%)\end{array}$ & $\begin{array}{c}10 \\
(13 \%)\end{array}$ & $\begin{array}{c}7 \\
(9 \%)\end{array}$ & \\
\hline $\begin{array}{l}\text { Taking } \\
\text { care of } \\
\text { elderly }\end{array}$ & $\begin{array}{c}12 \\
(16 \%)\end{array}$ & $\begin{array}{c}6 \\
(8 \%)\end{array}$ & $\begin{array}{c}0 \\
(0 \%)\end{array}$ & $\begin{array}{c}0 \\
(0 \%)\end{array}$ & $\begin{array}{c}2 \\
(3 \%)\end{array}$ & $\begin{array}{c}1 \\
(1 \%)\end{array}$ & $\begin{array}{c}15 \\
(20 \%)\end{array}$ & $\begin{array}{c}6 \\
(8 \%)\end{array}$ & \\
\hline
\end{tabular}

Source: Authors' calculation based on the survey data

The results presented in the Table 1 show that the women from the sample do the household chores mostly on their own, although a husband or partner may help with cooking and cleaning in the northern sub-sample, while husbands and partners from the southern sub-sample help more with the ironing. There is a subtly smaller participation of husbands/partners in taking care of small children and elderly in the southern subgroup.

Table 2. Degree of agreement of the participants with the following statements

\begin{tabular}{|c|c|c|c|c|c|c|}
\hline \multirow{2}{*}{ Statements } & \multicolumn{2}{|c|}{ I disagree } & \multicolumn{2}{|c|}{ I partially agree } & \multicolumn{2}{|c|}{ I agree } \\
\hline & North & South & North & South & North & South \\
\hline $\begin{array}{l}\text { If only one of the } \\
\text { spouses is working, it is } \\
\text { more natural for it to be } \\
\text { the man }\end{array}$ & $27(36.00 \%)$ & $\begin{array}{c}27 \\
(36.00 \%)\end{array}$ & $\begin{array}{c}29 \\
(38.67 \%)\end{array}$ & $\begin{array}{c}29 \\
(38.67 \%)\end{array}$ & $\begin{array}{c}28 \\
(37.33 \%)\end{array}$ & $\begin{array}{c}18 \\
(24.00 \%)\end{array}$ \\
\hline $\begin{array}{l}\text { The nature of household } \\
\text { chores is more suitable } \\
\text { for women. }\end{array}$ & $28(37.33 \%)$ & $\begin{array}{c}26 \\
(34.67 \%)\end{array}$ & $\begin{array}{c}38 \\
(37.33 \%)\end{array}$ & $\begin{array}{c}16 \\
(21.33 \%)\end{array}$ & $\begin{array}{c}19 \\
(25.33 \%)\end{array}$ & $\begin{array}{c}33 \\
(44.00 \%)\end{array}$ \\
\hline $\begin{array}{l}\text { Marriage equality is very } \\
\text { good, but it is usually } \\
\text { better that the male } \\
\text { spouse has the last say. }\end{array}$ & $55(73.33 \%)$ & $\begin{array}{c}34 \\
(45.33 \%)\end{array}$ & $\begin{array}{c}9 \\
(12.00 \%)\end{array}$ & $\begin{array}{c}20 \\
(26.67 \%)\end{array}$ & $9(12.00 \%)$ & $\begin{array}{c}20 \\
(26.67 \%)\end{array}$ \\
\hline $\begin{array}{l}\text { Employment of a female } \\
\text { spouse takes a big toll on } \\
\text { the family life. }\end{array}$ & $58(77.33 \%)$ & $\begin{array}{c}29 \\
(38.67 \%)\end{array}$ & $\begin{array}{c}9 \\
(12.00 \%)\end{array}$ & $\begin{array}{c}22 \\
(29.33 \%)\end{array}$ & $8(10.67 \%)$ & $\begin{array}{c}23 \\
(30.67 \%)\end{array}$ \\
\hline $\begin{array}{l}\text { Being a housewife can } \\
\text { be equally fulfilling for } \\
\text { a women, just as being } \\
\text { employed can. }\end{array}$ & $37(44.33 \%)$ & $\begin{array}{c}23 \\
(30.67 \%)\end{array}$ & $\begin{array}{c}21 \\
828.00 \%)\end{array}$ & $\begin{array}{c}21 \\
(28.00 \%)\end{array}$ & $\begin{array}{c}16 \\
(21.33 \%)\end{array}$ & $\begin{array}{c}31 \\
(41.33 \%)\end{array}$ \\
\hline $\begin{array}{l}\text { Family needs are } \\
\text { more important than } \\
\text { a woman's personal } \\
\text { ambition }\end{array}$ & $25(33.33 \%)$ & $\begin{array}{c}25 \\
(33.33 \%)\end{array}$ & $\begin{array}{c}24 \\
(32.00 \%)\end{array}$ & $\begin{array}{c}24 \\
(32.00 \%)\end{array}$ & $\begin{array}{c}25 \\
(33.33 \%)\end{array}$ & $\begin{array}{c}26 \\
(34.67 \%)\end{array}$ \\
\hline $\begin{array}{l}\text { Equality in marriage is } \\
\text { good, but it is better if a } \\
\text { male spouse earns more. }\end{array}$ & $34(45.33 \%)$ & $\begin{array}{c}28 \\
(37.33 \%)\end{array}$ & $\begin{array}{c}16 \\
(21.33 \%)\end{array}$ & $\begin{array}{c}22 \\
(29.33 \%)\end{array}$ & $\begin{array}{c}21 \\
(28.00 \%)\end{array}$ & $\begin{array}{c}23 \\
(30.67 \%)\end{array}$ \\
\hline
\end{tabular}

Source: Authors calculation based on the survey data 
The results shown in Table 2 reveal that the women entrepreneurs from the total sample only partially support the statement:,If only one of the spouses is working, it is more natural for it to be the man". Participants from the north mainly disagree (73.33\%) with the statement „Marriage equality is very good, but it is usually better that the male spouse has the last say” and with „Employment of a female spouse takes a big toll on the family life". A comment coming from one of the women entrepreneur participants from the south part of Serbia goes in favor of women emancipation, in spite of the divided attitudes toward traditionalism (shown equally in both sub-samples). Her comment was aimed at the statement ,Family needs are more important than a woman's personal ambition” and it was „I absolutely don't accept this attitude!"

Table 3. Support for the women entrepreneurs when they need advice or help

\begin{tabular}{|c|c|c|c|c|c|c|c|c|}
\hline $\begin{array}{l}\text { Situations in } \\
\text { which advice or } \\
\text { some form of } \\
\text { help is needed }\end{array}$ & 气ั & $\underset{\mathrm{\Xi}}{\overrightarrow{\mathrm{s}}}$ & 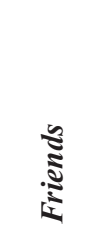 & 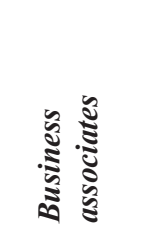 & 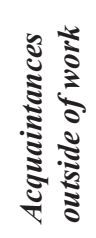 & 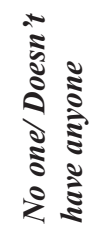 & 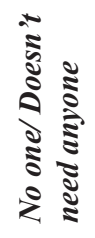 & 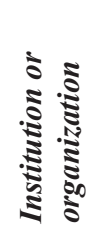 \\
\hline \multirow{2}{*}{$\begin{array}{l}\text { Gaining } \\
\text { information } \\
\text { regarding } \\
\text { business } \\
\text { opportunities } \\
\end{array}$} & $\mathbf{N}$ & $30(40 \%)$ & $\begin{array}{c}25 \\
(33 \%) \\
\end{array}$ & $26(35 \%)$ & $\begin{array}{c}9 \\
(12 \%) \\
\end{array}$ & $\begin{array}{c}2 \\
(3 \%) \\
\end{array}$ & $\begin{array}{c}1 \\
(1 \%) \\
\end{array}$ & $\begin{array}{c}9 \\
(12 \%) \\
\end{array}$ \\
\hline & $\mathbf{S}$ & $41(55 \%)$ & $\begin{array}{c}12 \\
(16 \%)\end{array}$ & $\begin{array}{c}31 \\
(41 \%)\end{array}$ & $\begin{array}{c}15 \\
(20 \%)\end{array}$ & $\begin{array}{c}2 \\
(3 \%)\end{array}$ & $\begin{array}{c}1 \\
(1 \%)\end{array}$ & $\begin{array}{c}1 \\
(1 \%)\end{array}$ \\
\hline \multirow{2}{*}{$\begin{array}{l}\text { Finding an } \\
\text { employee } \\
\text { of certain } \\
\text { qualifications }\end{array}$} & $\mathbf{N}$ & $\begin{array}{c}18 \\
(24 \%) \\
\end{array}$ & $\begin{array}{c}34 \\
(45 \%) \\
\end{array}$ & $\begin{array}{c}15 \\
(20 \%) \\
\end{array}$ & $\begin{array}{c}10 \\
(13 \%) \\
\end{array}$ & $\begin{array}{c}3 \\
(4 \%) \\
\end{array}$ & $\begin{array}{c}5 \\
(7 \%) \\
\end{array}$ & $\begin{array}{c}8 \\
(11 \%) \\
\end{array}$ \\
\hline & $\mathbf{S}$ & $32(43 \%)$ & $\begin{array}{c}28 \\
(37 \%) \\
\end{array}$ & $22(29 \%)$ & $\begin{array}{c}8 \\
(11 \%) \\
\end{array}$ & $\begin{array}{c}2 \\
(3 \%) \\
\end{array}$ & $\begin{array}{c}1 \\
(1 \%) \\
\end{array}$ & $\begin{array}{c}0 \\
(0 \%) \\
\end{array}$ \\
\hline \multirow{2}{*}{$\begin{array}{l}\text { Advice or support } \\
\text { in times of } \\
\text { business crisis }\end{array}$} & $\mathbf{N}$ & $\begin{array}{c}44 \\
(59 \%)\end{array}$ & $\begin{array}{c}25 \\
(33 \%)\end{array}$ & $\begin{array}{c}15 \\
(21 \%) \\
\end{array}$ & $\begin{array}{c}1 \\
(1 \%)\end{array}$ & $\begin{array}{c}2 \\
(3 \%)\end{array}$ & $\begin{array}{c}2 \\
(3 \%)\end{array}$ & $\begin{array}{c}3 \\
(4 \%) \\
\end{array}$ \\
\hline & $\mathbf{S}$ & $50(67 \%)$ & $\begin{array}{c}17 \\
(23 \%) \\
\end{array}$ & $20(27 \%)$ & $\begin{array}{c}8 \\
(11 \%) \\
\end{array}$ & $\begin{array}{c}2 \\
(3 \%) \\
\end{array}$ & $\begin{array}{c}1 \\
(1 \%) \\
\end{array}$ & $\begin{array}{c}0 \\
(0 \%) \\
\end{array}$ \\
\hline \multirow{2}{*}{$\begin{array}{l}\text { Help concerning } \\
\text { paperwork on } \\
\text { the job }\end{array}$} & $\mathbf{N}$ & $\begin{array}{c}15 \\
(21 \%) \\
\end{array}$ & $\begin{array}{c}12 \\
(16 \%) \\
\end{array}$ & $\begin{array}{c}37 \\
(49 \%) \\
\end{array}$ & $\begin{array}{c}4 \\
(5 \%) \\
\end{array}$ & $\begin{array}{c}1 \\
(1 \%) \\
\end{array}$ & $\begin{array}{c}4 \\
(5 \%) \\
\end{array}$ & $\begin{array}{c}0 \\
(0 \%) \\
\end{array}$ \\
\hline & $S$ & $36(48 \%)$ & $\begin{array}{c}17 \\
(23 \%) \\
\end{array}$ & $33(44 \%)$ & $\begin{array}{c}4 \\
(5 \%) \\
\end{array}$ & $\begin{array}{c}1 \\
(1 \%) \\
\end{array}$ & $\begin{array}{c}2 \\
(3 \%) \\
\end{array}$ & $\begin{array}{c}0 \\
(0 \%) \\
\end{array}$ \\
\hline \multirow{2}{*}{$\begin{array}{l}\text { Finding a } \\
\text { replacement } \\
\text { when ill }\end{array}$} & $\mathbf{N}$ & $\begin{array}{c}43 \\
(57 \%) \\
\end{array}$ & $\begin{array}{c}18 \\
(24 \%) \\
\end{array}$ & $\begin{array}{c}17 \\
(23 \%) \\
\end{array}$ & $\begin{array}{c}1 \\
(1 \%)\end{array}$ & $\begin{array}{c}2 \\
(3 \%) \\
\end{array}$ & $\begin{array}{c}1 \\
(1 \%)\end{array}$ & $\begin{array}{c}3 \\
(4 \%) \\
\end{array}$ \\
\hline & $\mathbf{S}$ & $49(65 \%)$ & $\begin{array}{c}16 \\
(21 \%) \\
\end{array}$ & $17(23 \%)$ & $\begin{array}{c}5 \\
(7 \%) \\
\end{array}$ & $\begin{array}{c}1 \\
(1 \%) \\
\end{array}$ & $\begin{array}{c}2 \\
(2 \%) \\
\end{array}$ & $\begin{array}{c}0 \\
(0 \%) \\
\end{array}$ \\
\hline \multirow{2}{*}{$\begin{array}{l}\text { Urgent money } \\
\text { loan }\end{array}$} & $\mathbf{N}$ & $\begin{array}{c}38 \\
(51 \%) \\
\end{array}$ & $\begin{array}{c}22 \\
(29 \%) \\
\end{array}$ & $\begin{array}{c}7 \\
(9 \%) \\
\end{array}$ & $\begin{array}{c}6 \\
(8 \%) \\
\end{array}$ & $\begin{array}{c}3 \\
(4 \%) \\
\end{array}$ & $\begin{array}{c}5 \\
(7 \%) \\
\end{array}$ & $\begin{array}{c}2 \\
(3 \%) \\
\end{array}$ \\
\hline & S & $51(68 \%)$ & $\begin{array}{c}12 \\
(16 \%) \\
\end{array}$ & $23(31 \%)$ & $\begin{array}{c}1 \\
(1 \%) \\
\end{array}$ & $0(0 \%)$ & $\begin{array}{c}11 \\
(15 \%) \\
\end{array}$ & $\begin{array}{c}2 \\
(3 \%) \\
\end{array}$ \\
\hline
\end{tabular}

Source: Authors calculation based on the survey data 
When it comes to asking for support in situations where some kind of information is needed, finding a replacement when they ill, an urgent money loan and similar, from Table 3 it is noticeable that women entrepreneurs from both parts of Serbia are relying on their family, friends and business associates. Observable is also a poor level of communication with institutions or organizations such as offices for local economic development, the department for commerce in local self-government, National Employment Service, loan institutions, women entrepreneur societies and similar institutions.

Before founding an entrepreneurial store/firm or a registration of agrarian husbandry, entrepreneurs from the northern part of Serbia were more likely to be officially employed or were actively seeking employment while the entrepreneurs from the southern part were mostly unofficially self-employed and already had a firm/husbandry whose activities were shut down (north $3(4 \%)$, south $9(12 \%)$ ).

It is estimated that businesses started with entrepreneurial ideas provide $75 \%$ of new working places in the commerce every year. The main motivators for opening their own businesses for women from this sample were independence, good ideas or opportunities, increased earnings, family traditions, coordinating career and family duties, converting hobbies into work etc. Entrepreneurs from the populated places in the north were driven by unemployment or by doing jobs that are directly related to their profession, but the women from the south of Serbia were motivated by too much free time that they hand on their hands after raising their children. In close or extended families, the entrepreneur was usually the father of these women entrepreneurs (north $13(16 \%)$, south $24(32 \%))$.

The business climate in Serbia - as far as availability of the financial capital is concerned, complexity of the administrative procedures and possibilities of getting a second chance for starting agribusiness and business in general - was rated by the women in the total sample, with the women from the north rating it between 1-2, while the women from the south rated 2-3 (the range of marks goes from 1 to 5, where one is the lowest and 5 is the highest score). Entrepreneurs from the whole sample rated the risk of failing at 2.46, which in some way is not consistent with the previous answers, and thus indicates either a lack of attention when answering or insufficient knowledge regarding business opportunities.

Before these entrepreneurs started their own businesses, they had attended specific courses in order to prepare them for their future ventures. Women from the south attended mostly courses for entrepreneurial development, craft courses and courses for services, while the women from the north took courses for entrepreneurial development, courses for enhancing their knowledge in bookkeeping, accountancy, managing paperwork, learning more about law procedures and laws, as well as courses which developed their communication, marketing and managerial skills. 
Graph 1. Useful business connections during the business setup

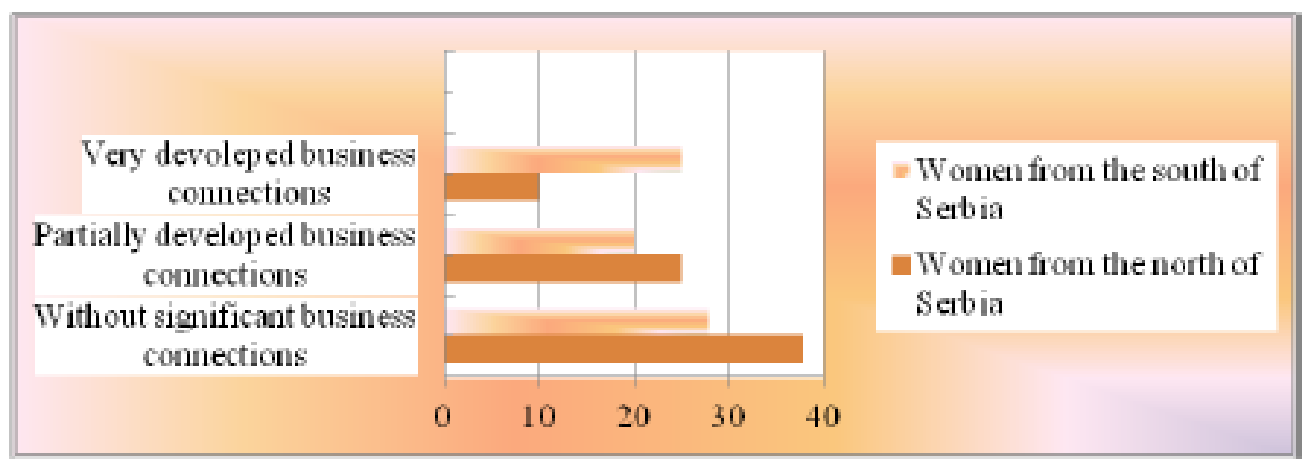

Source: Authors calculation based on the survey data

When these women were starting their own businesses, they all had different business experiences (Graph 1) which contributed to the creation of useful work connections (social resources), as stated by $35(46.67 \%)$ women from populated places in the north and $45(60 \%)$ women from the sample from the populated southern parts of Serbia. Only $19(25.33 \%)$ participants from the north had previous managerial experience, and $34(45.33 \%)$ from the south. This proves that for starting your own business, prior top managerial experience is not essential, but continuous education, strengthening of the communication skills, developing business and social contacts with professional help are vital. Because of this, in the last 30 years there has been a dramatic increase for market and concurrent information and the smart synthesis of this information. Services like these, together with institutions specialized in providing them, are offered by management consultants (Cvijanović et al., 2010)

There is a significant difference in the business approach among female entrepreneurs from questioned sub-samples; the entrepreneurs from the south are under a stronger influence from family tradition regarding entrepreneurship, entrepreneurial and managerial experience and they usually seek professional advice and loans when it comes to starting their own business (north $8(10.67 \%)$, south 26(75\%)). The conclusions that can be drawn from the entrepreneurial experience are as well as macroeconomic stability - the first factor that has an influence on the success of the form - there is also an impact of the innovation in the firm it self. Alongside consulting services, innovation with business strategies and finances is crucial. According to research carried out by Mihailović (2011), these two factors describe more than 50\% of the variance in the performance quality of the agri-complexes in Serbia.

Women entrepreneurs from the populated places in the north of Serbia are involved in trade (26-34.67\%), classical services (17-22,67\%), agrarian business (12-16\%) and information technologies, finances, real-estate and scientific and technological development (8-10.67\%) and catering industry (7-9.33\%), while in the south (24-32\%) the population is engaged in agrarian activities, trade (17-22.67\%), administrative and social services (10-13.33\%), catering industry (7-9.33\%), classical services $(6-8.00 \%)$ 
and entrepreneurial activities in traffic (6-8.00\%).

The participants firms or agrarian husbandry from the both subgroups are mostly carrying out business on the local market (north 50 (66.67\%), south $48(64 \%)$ ). There are only 3 firms (4\% of the sample) from the northern sub-sample trading on the European Union market.

Turnover in most of the firms/agrarian husbandries in the past year was approximately the same 2-4 million dinars (RSD) (north 66 (88.00\%), south (81.33\%). Participants largely either stated that the turnover had decreased compared to last year due to financial crises (north $41(54.67 \%)$ ) or stated that it stayed the same (south $43(57.33 \%)$ ) (Picture 1).

Picture 1. Changes in earnings in firms/agrarian husbandries compared to last years

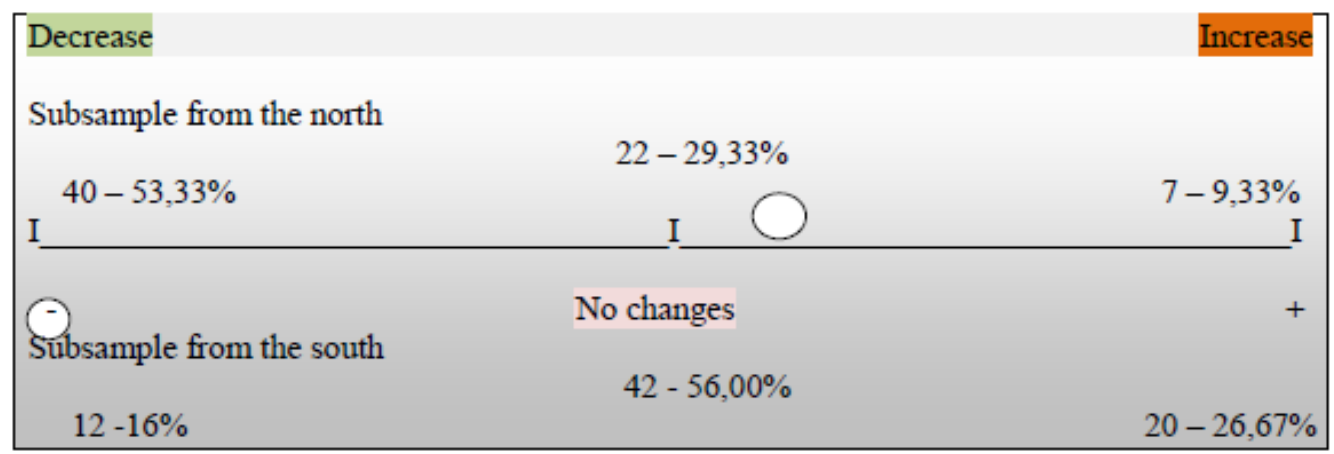

Source: Authors' calculation based on the survey data

Gains by the firms/agrarian husbandry in the past year was small/sufficient and good compared to previous periods in the both sub-samples (north 60 (80.00\%), south 52 $(66.33 \%))$, which is partially confirmed by answers on the control question regarding intensity of change of the gain: decreased (north $24(32.00 \%)$, south $19(25.33 \%)$ ), no changes (north $25(33.33 \%)$, south $23(30.67 \%)$ ) and increased (north $9(12 \%)$, south $24(32 \%))$.

Discrepancy in the answers regarding the assessment of the last year's turnover compared to past periods between women from the south and the north is so small it can be disregarded. One of the reasons for that is the fact that only descriptive measures were included in the questionnaire. Nevertheless, women entrepreneurs have rated their businesses as stagnant (north 33 (44\%), south $19(25.33 \%)$ ), and successful (north 23 (30.67\%), and south $43(57.33 \%))$.

The basic elements of entrepreneurship are innovations which encompass: implementing new organizational structure, implementing new technology, discovering new energy resources, introducing new products, introducing new work methods and similar (Pejanović, 2010). 31 (41.33\%) Entrepreneurs from the north of Serbia have been introducing innovations of products and services for the past two years, while $19(25.33 \%)$ said they introduced stronger marketing support for other areas of their business. On the other hand, entrepreneurs from the south have innovated the inner 
organization of the firm, $24(32.00 \%)$, product and service innovation, $23(30.67 \%)$, and innovations in marketing, $21(28 \%)$.

As far as income increases in the next two years are concerned, women from both subgroups stated that they are planning to hire additional workers, and invest in new products, services and marketing. Women from the north declared the intention of increasing their employees' salaries (north 15 (20\%), south 5 (6.67\%), and a higher portion of women from the south stated they plan on keeping most of the gain (north $6(8 \%)$, south $12(16 \%)$, which is not in accordance with previous answers, nor the experience and entrepreneurial tradition of women from the south.

Table 4. Intensity of engagement of the entrepreneurial women in other organizations and societies

\begin{tabular}{|l|c|c|c|c|c|c|}
\hline \multirow{2}{*}{$\begin{array}{l}\text { Intensity of engagement } \\
\text { Type of association }\end{array}$} & \multicolumn{2}{|l|}{ Active } & \multicolumn{2}{l|}{ Passive } & \multicolumn{2}{|l|}{ Not a member } \\
\cline { 2 - 7 } & North & South & North & South & North & South \\
\hline Employers' association & 9 & 25 & 11 & 20 & 50 & 30 \\
& $(12 \%)$ & $(33 \%)$ & $(15 \%)$ & $(27 \%)$ & $(67 \%)$ & $(40 \%)$ \\
\hline $\begin{array}{l}\text { Association of the peopleof } \\
\text { same profession }\end{array}$ & 17 & 15 & 15 & 34 & 39 & 25 \\
\hline Sports/recreation society & $(23 \%)$ & $(20 \%)$ & $(20 \%)$ & $(45 \%)$ & $(52 \%)$ & $(33 \%)$ \\
\hline Art/education society & 7 & 20 & 14 & 24 & 49 & 29 \\
\hline Humanitarian organization & $(9 \%)$ & $(27 \%)$ & $(19 \%)$ & $32 \%)$ & $(65 \%)$ & $(39 \%)$ \\
\hline & $(21 \%)$ & $(17 \%)$ & $(19 \%)$ & $(25 \%)$ & $(53 \%)$ & $(55 \%)$ \\
\hline
\end{tabular}

Source: Authors calculation based on the survey data

Generally speaking, entrepreneurs from both subgroups do not show high levels of engagement with any of these organizations, from employers' associations to humanitarian organizations. There is a certain deviation in the southern subgroup (see Table 4), which is understandable considering the fact that there is specific entrepreneurial family tradition, which has offered stronger communications through connecting via organizations. 
Table 5: Intensity of the possible problematic situations

\begin{tabular}{|c|c|c|c|c|c|c|}
\hline $\begin{array}{l}\text { Intensity of the problem } \\
\text { Type of problem }\end{array}$ & Sample & Never & Occasionally & Rarely & Often & $\begin{array}{l}\text { Can't } \\
\text { asses }\end{array}$ \\
\hline \multirow{2}{*}{$\begin{array}{l}\text { To come home from work, too } \\
\text { exhausted to do house chores. }\end{array}$} & North & $\begin{array}{c}4 \\
(5 \%) \\
\end{array}$ & $\begin{array}{c}12 \\
(16 \%) \\
\end{array}$ & $\begin{array}{c}25 \\
(33 \%) \\
\end{array}$ & $\begin{array}{r}26 \\
(35 \%) \\
\end{array}$ & $\begin{array}{r}3 \\
(4 \%) \\
\end{array}$ \\
\hline & South & $\begin{array}{c}21 \\
(28 \%) \\
\end{array}$ & $\begin{array}{c}25 \\
(33 \%) \\
\end{array}$ & $\begin{array}{c}4 \\
(5 \%) \\
\end{array}$ & $\begin{array}{c}21 \\
(28 \%) \\
\end{array}$ & $\begin{array}{c}4 \\
(5 \% 9 \\
\end{array}$ \\
\hline \multirow{2}{*}{$\begin{array}{l}\text { Conflict of the time spent on the } \\
\text { work and time spent in home- } \\
\text { family duties. }\end{array}$} & North & $\begin{array}{c}8 \\
(11 \%)\end{array}$ & $\begin{array}{c}16 \\
(21 \%)\end{array}$ & $\begin{array}{c}26 \\
(35 \%)\end{array}$ & $\begin{array}{c}20 \\
(27 \%)\end{array}$ & $\begin{array}{c}8 \\
(11 \%)\end{array}$ \\
\hline & South & $\begin{array}{c}17 \\
(23 \%) \\
\end{array}$ & $\begin{array}{c}21 \\
(28 \%) \\
\end{array}$ & $\begin{array}{l}15 \\
(2 \%) \\
\end{array}$ & $\begin{array}{c}22 \\
(29 \%) \\
\end{array}$ & $\begin{array}{c}0 \\
(0 \%)\end{array}$ \\
\hline \multirow{2}{*}{$\begin{array}{l}\text { Poor concentration during family } \\
\text { activities }\end{array}$} & North & $\begin{array}{c}11 \\
(15 \%) \\
\end{array}$ & $\begin{array}{c}20 \\
(27 \%) \\
\end{array}$ & $\begin{array}{c}22 \\
(29 \%) \\
\end{array}$ & $\begin{array}{c}14 \\
(19 \%) \\
\end{array}$ & $\begin{array}{c}1 \\
(1 \%) \\
\end{array}$ \\
\hline & South & $\begin{array}{c}11 \\
(15 \%) \\
\end{array}$ & $\begin{array}{r}29 \\
(39 \%) \\
\end{array}$ & $\begin{array}{r}19 \\
(25 \%) \\
\end{array}$ & $\begin{array}{c}16 \\
(21 \%) \\
\end{array}$ & $\begin{array}{r}0 \\
(0 \%) \\
\end{array}$ \\
\hline \multirow{2}{*}{$\begin{array}{l}\text { Come to work and feel too tired to } \\
\text { do work tasks. }\end{array}$} & North & $\begin{array}{c}14 \\
(19 \%) \\
\end{array}$ & $\begin{array}{c}14 \\
(19 \%) \\
\end{array}$ & $\begin{array}{c}31 \\
(41 \%) \\
\end{array}$ & $\begin{array}{c}9 \\
(12 \%) \\
\end{array}$ & $\begin{array}{r}3 \\
(4 \%) \\
\end{array}$ \\
\hline & South & $\begin{array}{c}28 \\
(37 \%) \\
\end{array}$ & $\begin{array}{c}15 \\
(20 \%) \\
\end{array}$ & $\begin{array}{c}15 \\
(20 \%) \\
\end{array}$ & $\begin{array}{c}16 \\
(21 \%) \\
\end{array}$ & $\begin{array}{c}1 \\
(1 \%) \\
\end{array}$ \\
\hline \multirow{2}{*}{$\begin{array}{l}\text { Conflict of the time spent on the } \\
\text { work and time spent in home-work } \\
\text { duties. }\end{array}$} & North & $\begin{array}{c}13 \\
(17 \%)\end{array}$ & $\begin{array}{c}16 \\
(21 \%)\end{array}$ & $\begin{array}{c}23 \\
(31 \%)\end{array}$ & $\begin{array}{c}17 \\
(23 \%)\end{array}$ & $\begin{array}{c}3 \\
(4 \%)\end{array}$ \\
\hline & South & $\begin{array}{c}14 \\
(19 \%) \\
\end{array}$ & $\begin{array}{c}17 \\
(23 \%) \\
\end{array}$ & $\begin{array}{c}21 \\
(28 \%) \\
\end{array}$ & $\begin{array}{c}18 \\
(24 \%) \\
\end{array}$ & $\begin{array}{c}5 \\
(7 \%) \\
\end{array}$ \\
\hline \multirow{2}{*}{$\begin{array}{l}\text { Poor concentration at work due to } \\
\text { family duties. }\end{array}$} & North & $\begin{array}{c}18 \\
(24 \%) \\
\end{array}$ & $\begin{array}{c}20 \\
(26 \%) \\
\end{array}$ & $\begin{array}{c}26 \\
(35 \%) \\
\end{array}$ & $\begin{array}{c}5 \\
(7 \%) \\
\end{array}$ & $\begin{array}{c}2 \\
(3 \%) \\
\end{array}$ \\
\hline & South & $\begin{array}{c}22 \\
(29 \%) \\
\end{array}$ & $\begin{array}{c}17 \\
(23 \%) \\
\end{array}$ & $\begin{array}{c}16 \\
(21 \%) \\
\end{array}$ & $\begin{array}{c}19 \\
(25 \%) \\
\end{array}$ & $\begin{array}{r}2 \\
(3 \%) \\
\end{array}$ \\
\hline \multirow{2}{*}{$\begin{array}{l}\text { Conflict situations with distributors, } \\
\text { colleagues, customers or other } \\
\text { stakeholders. }\end{array}$} & North & $\begin{array}{c}21 \\
(28 \%) \\
\end{array}$ & $\begin{array}{r}27 \\
(36 \%) \\
\end{array}$ & $\begin{array}{c}18 \\
(24 \%) \\
\end{array}$ & $\begin{array}{c}2 \\
(3 \%) \\
\end{array}$ & $\begin{array}{r}3 \\
(4 \%) \\
\end{array}$ \\
\hline & South & $\begin{array}{c}24 \\
(32 \%) \\
\end{array}$ & $\begin{array}{c}20 \\
(27 \%) \\
\end{array}$ & $\begin{array}{c}17 \\
(23 \%) \\
\end{array}$ & $\begin{array}{c}14 \\
(19 \%) \\
\end{array}$ & $\begin{array}{c}0 \\
(0 \%) \\
\end{array}$ \\
\hline
\end{tabular}




\begin{tabular}{|c|c|c|c|c|c|c|}
\hline $\begin{array}{l}\text { Intensity of the problem } \\
\text { Type of problem }\end{array}$ & Sample & Never & Occasionally & Rarely & Often & $\begin{array}{l}\text { Can't } \\
\text { asses }\end{array}$ \\
\hline \multirow{2}{*}{$\begin{array}{l}\text { If there are conflicts: Are they } \\
\text { based on gender discrimination? }\end{array}$} & North & $\begin{array}{c}41 \\
(55 \%) \\
\end{array}$ & $\begin{array}{c}9 \\
(12 \%) \\
\end{array}$ & $\begin{array}{c}7 \\
(9 \%) \\
\end{array}$ & $\begin{array}{c}2 \\
(3 \% 9 \\
\end{array}$ & $\begin{array}{c}12 \\
(16, \%) \\
\end{array}$ \\
\hline & South & $\begin{array}{c}37 \\
(49 \%)\end{array}$ & $\begin{array}{c}13 \\
(17 \%)\end{array}$ & $\begin{array}{c}9 \\
(12 \%)\end{array}$ & $\begin{array}{c}16 \\
(21 \%)\end{array}$ & $\begin{array}{c}0 \\
(0 \%)\end{array}$ \\
\hline \multirow{2}{*}{$\begin{array}{l}\text { Conflict situations with the } \\
\text { environment, tenants in the } \\
\text { neighborhood of the business } \\
\text { offices and similar. }\end{array}$} & North & $\begin{array}{c}34 \\
(45 \%) \\
\end{array}$ & $\begin{array}{c}16 \\
(21, \%) \\
\end{array}$ & $\begin{array}{c}14 \\
(19 \%) \\
\end{array}$ & $\begin{array}{c}2 \\
(3 \%) \\
\end{array}$ & $\begin{array}{c}4 \\
(5 \%) \\
\end{array}$ \\
\hline & South & $\begin{array}{r}32 \\
(43 \%) \\
\end{array}$ & $\begin{array}{c}15 \\
(23 \%) \\
\end{array}$ & $\begin{array}{c}11 \\
(15 \%)\end{array}$ & $\begin{array}{c}13 \\
(17 \%)\end{array}$ & $\begin{array}{c}13 \\
(17 \%)\end{array}$ \\
\hline \multirow{2}{*}{$\begin{array}{l}\text { If there are conflicts: Are they } \\
\text { based on gender discrimination? }\end{array}$} & North & $\begin{array}{c}44 \\
(9 \%) \\
\end{array}$ & $\begin{array}{c}9 \\
(12 \%) \\
\end{array}$ & $\begin{array}{c}4 \\
(5 \%) \\
\end{array}$ & $\begin{array}{c}4 \\
(5 \%) \\
\end{array}$ & $\begin{array}{c}7 \\
(9 \%) \\
\end{array}$ \\
\hline & South & $\begin{array}{c}35 \\
(47 \%)\end{array}$ & $\begin{array}{c}18 \\
(24 \%)\end{array}$ & $\begin{array}{c}5 \\
(7 \%)\end{array}$ & $\begin{array}{c}13 \\
(17 \%)\end{array}$ & $\begin{array}{c}3 \\
(4 \%)\end{array}$ \\
\hline
\end{tabular}

Source: Authors calculation based on the survey data

More women from the northern subgroup had come home from work too tired to do house chores compared to women from the south. There is a registered conflict between time spent on work and time spent at home doing family duties, with both groups of women saying they have bad concentration when it comes to doing family activities due to overwhelming business duties (Table 5).

Even though the women from the southern subgroup exhibit less tiredness on work due to household activities than the women from the north, they still show better focus during work hours despite family activities. However they do still feel the equal conflict of the time spent home and time spent on work.

Conflicts with distributors, colleagues, consumers, and the environment near the business's offices have low visibility in both of the subgroups, but the southern subsample stated that, even if some sort of conflict occurs in the office neighborhood, it is usually based on gender discrimination.

In terms of advice for prospective women entrepreneurs, women entrepreneurs from the north have the following messages: engage in continuous education; rely on your intuition, but also on the professional assistance of institutions, friends and family; listen to other peoples' experiences; become a part of societies related to your profession; visit all sorts of events, forums, etc. Synergy and useful information are the key to leading a successful business. The conclusion can be drawn (Keh, 2006) that acquiring and applying information isn't a one time event, but an ongoing process through everyday 
interaction with customers, distributors and other business associates.

Furthermore, it is very important to make a balance between risky and cautious ways of leading a business. The risk taking dimension is positively related to high performances of entrepreneurial firms (Naldi, 2007), but the successfulness of the entrepreneurial process (Pejanović, 2010) is also subject to other crucial factors such as: entrepreneurial opportunities (the presence of favorable market options and good perception of the business possibilities); and entrepreneurial capacity (which enables starting new jobs that are satisfying the market opportunities and which primarily brings the motivation to enter the world of entrepreneurship and having adequate knowledge and skills needed to actualize a business opportunity).

\section{Conclusion}

Entrepreneurship represents "creative destruction"; that is, the application of continuous innovations and constant market monitoring. Female entrepreneurship enables a strengthening of gender equality, which is one of the indicators of the economic development of a modern society. Tradition and the patriarchic way of upbringing remains an obstacle, but as shown by market research it can also provide a form of support in some areas.

The hypothesis in this research poses that female entrepreneurship in rural areas is not broadly represented, and it has been confirmed by establishing personal contact with some of the women entrepreneurs, societies and associations. There is not an all encompassing database available, aside from the gender non-sensitive data provided by the Agency for Commerce Registries which consists only of previously collected contacts of entrepreneurs. The research was done in several stages, until the sample of 75 participants from north and 75 participants from south of Serbia was reached.

By employing comparative analysis, the profile of the entrepreneurs was compiled including their family and business environment, personal attitudes and business issues in both subgroups of the sample. Also, a number of key motivators and obstacles for opening a business were revealed by authentic replies given in the survey. The questions were asking what they change generally or in their surrounding, in order to enhance the number of women entrepreneurs in villages.

These are the answers of the women from the northern part of Serbia: "The number of female entrepreneurs could be enhanced by raising the level of awareness regarding the importance of the entrepreneurial way of thinking via specialized education, trainings, courses, forums, entrepreneurial exhibits and fairs, examining visits of the environments in Serbia and abroad which have developed entrepreneurial traditions; establishing more services for taking care of children and helping families (accommodated services such as: kindergartens with flexible working hours, day cares for elderly...); by founding societies and creating a network between available services via modern ways of communication; stronger media support; by eliminating "obstacles" posed by society and government, removing all the taxes apart from the tax on added value 
and other non-fiscal deals; simplification of administrative measures; by giving more financial incentives such as creating funds for female entrepreneurs starting their own business, starting at the local level; changing business climate and providing stronger levels of state support; increasing positive discrimination of women; and incorporating entrepreneurial education in elementary schools", since $58 \%$ of young people claimed they don't have any intention of starting their own businesses in the next 5 years (Citizens' initiatives, 2012).

Answers coming from the women from the south of Serbia: "The number of female entrepreneurs would be significantly higher if a program for empowering female entrepreneurship was developed; by entrepreneurial education and education in every sense; raising collective awareness regarding gender equality, increasing support from families and the environment; influencing collective awareness of women-encouraging proactivity; better and clearer communication and information flow; establishing associations; stronger support from the government; changing the conditions of business and women's' position in the society in general; founding trust funds, starting at the local level; building missing infrastructure in populated areas; changing certain laws, especially ones regarding product import and export; facilitate product placing on regional, EU, and world markets; introducing series of benefits and changing work climate; and the adaptation of certain laws and regulations."

From the above stated recommendations (which are already partially applied in some rural areas), the strongest attitude is that entrepreneurship is in fact a profession and that it needs to be studied early in life, in elementary schools even. It is necessary to create a compulsory national networked system of business communication and correspondence for women entrepreneurs with the inclusion of consulting favors. With the help of associations, societies and informal pressure groups, coercion should be applied to present the issues facing female entrepreneurs to the appropriate adequate institutions, initially focusing on regional differences in order to change specific administrative measures, soften legal restrictions and create rural policies in politics relating to specific areas which can help women entrepreneurs.

\section{References}

1. Bock, B. B. (2010): Personal and social development of women in rural areas of Europe, European Parliament's Committee on Agriculture and Rural Development, IP/B/AGRI/IC/2010_089, Brussels, Belgium (available at: www.europarl.europa. $\mathrm{eu} /$ studies).

2. Cvijanović, D., Mihailović, B. (2010): Menadžmen ti marketing uslužnog sektora, Institut za ekonomiku poljoprivrede Belgrade, Belgrade, Serbia.

3. Cvijanović, D. (2012): Kako povećati konkurentnost i suficit Republike Srbije, Institut za ekonomiku poljoprivrede Belgrade, Belgrade, Serbia.

4. Čikić, J., Petrović, M.., Petrović, Ž. (2011): Žene u selu i razvoj preduzetništva, Ekonomika poljoprivrede, Naučno društvo agrarnih ekonomista Balkana, Belgrade, 
Serbia, Institut za ekonomiku poljoprivrede, Belgrade, Serbia, Vol. 58, No. 1-368, pp. 223-230.

5. Datta,P. B., Gailey, R. (2012): Empowering Women Through SocialEntrepreneurship: Case Study of a Women's Cooperative in India. Entrepreneurship Theory and Practice, Blackwell Publishing, Inc., Malden, Massachusetts, USA, Vol. 36, No. 3, pp. 569-587.

6. Đekić, S., Jovanović, S., Krstić, B. (2011): Neke determinante kreiranja politike $i$ strategije održivog ruralnog razvoja, Agrarna i ruralna politika u Srbiji - Nužnost ubrzanja reformi, Društvo agrarnih ekonomista Srbije, Ekonomski fakultet, Univerzitet u NovomSadu, Belgrade, Novi Sad, Serbia, pp. 49-65.

7. Đurašević, S. (2009): Klasteri kao osnova regionalnog razvoja u turizmu, Montenegrin Journal of Economics, Fakultet za turizam u Baru. Univerzitet “'Mediteran" Podgorica, Crna Gora, No 9, pp. 101-109, avaliable at www.repec. mnje.com/mje/2009/v05-n09/mje 2009 v05-n09-a17.pdf.

8. EU progres (2015): Komponenta 1 - Dobro upravljanje.Agenda rodne ravnopravnosti: Podrška ženskom preduzetništvu kroz grantove za pokretanje biznisa, EU, (available at: www.euprogres.org/.../2_460_Supporting_Women_E ).

9. Jones, C. English, J. (2004): A contemporary approach to entrepreneurship education. Education + Training, Vol. 46., No 8/9 .pp. 416-423, Emerald Group, Australia, available at: www.eprints.utas.edu.au/828/1/p416.pdf .

10. Keh, H.T., Mai. T.T., Ng, H. P. (2006): The effects of entrepreneurial orientation and marketing information on the performance of SMEs, Journal of Business Venturing, Vol. 22, Iss. 4, pp. 592-611, Luxembourg Business Academy, University of Luxembourg, Luxembourg, available at: www.sciencedirect.com/science/article/ pii/S0883902606000498.

11. Mihailović, B. (2011): Razvoj konsultantskih usluga u Srbiji i njihov uticaj na performanse preduzeća u agrokompleksu., Institut za ekonomiku poljoprivrede Belgrade, Belgrade, Serbia.

12. Naldi, L., Nordqvist, M., Karin Sjöberg, K., Wiklund, J. (2007): Entrepreneurial Orientation, Risk Taking, and Performance in Family Firms, Family Business Review, Vol. XX., No 1., pp. 33-47. Swedish. available at: www.alexandria.unisg. ch/export/DL/62491.pdf.

13. Pejanović, R., Njegovan, Z. (2010): Preduzetništvo kao razvojni resurs (agro) privrede Republike Srbije, Agroekonomika, Poljoprivredni fakultet, Univerzitet $\mathrm{u}$ NovomSadu, Novi Sad, Serbia, Vol 45-46, No. 45-46, pp. 5-15.

14. Pejanović, R., Njegovan, Z. (2011): Ruralni razvoj i lokolno ekonomski razvoj AP Vojvodine. Poljoprivredni fakultet, Univerzitet u NovomSadu, Novi Sad, Serbia.

15. Pejanović, R. (2013): Ogledi iz agrarne i ruralne ekonomije, Poljoprivredni fakultet, Univerzitet u NovomSadu, Novi Sad, Serbia.

16. Pejanović, R., Cerović, B. (2015): Kako povećati zaposlenost u Srbiji, Univerzitet 
u Novom Sadu i Naučno društvo ekonomista Srbije-Belgrade, Novi Sad, Serbia.

17. Njegovan, Z. (2001): Od planski orijentisane ka tržišno orijentisanoj i održivoj ekonomiji - Predlozi planiranja agrarnog razvoja, Industrija, Ekonomski institut, Belgrade, Serbia, Vol. 27, No. 1-4, pp. 9-19.

18. Stojanović, M., Radaković, D., Šolić, Vojinović, M., Bubanja, J. (2012): Državna služba? Ne hvala, ja sam preduzetnica!, Građanske inicijative, Belgrade, Serbia, available at: www.repec.mnje.com/.../mje 2009 v05-n09-a17.pdf.

19.Van Praag, C. M., Van der Sluis, J., Van Witteloostuijn, A. (2004): The Impact of the Locus-of-Control Personality Trait on the Earnings of Employees vis-àvis Entrepreneurs, Tinbergen Institute Discussion Paper, TI 2004-130/3, UvADARE, the institutional repository of the University of Amsterdam (UvA), Holand, (avaliable at: www.books.google.rs/books?isbn=1849808457).

20. Vlahović, B. (2013): Tržište agroindustrijskih proizvoda, Poljoprivredni fakultet. Univerzitet u NovomSadu, Novi Sad, Serbia.

21. Winn, J. (2005): Women Entrepreneurs: Can We Remove the Barriers? International Entrepreneurship and Management Journal, Springer US, New York, USA, Vol. 1, No. 3, pp. 381-397.

22. Winn, J. (2004): Entrepreneurship: Not an easy path to top management for women. Women in Management Review, Emerald Group, Bradford, United Kingdom, Vol. 19 , no. 3, pp. 143-153. 


\title{
PREGLED ISTRAŽIVANJA ŽENSKOG AGRARNOG PREDUZETNIŠTVA U REPUBLICI SRBIJI
}

\author{
Maksimović Goran $^{5}$, Otović Slavica ${ }^{6}$, Demirović Dunja ${ }^{7}$, Tatjana Vermezović ${ }^{8}$
}

\begin{abstract}
Rezime
Rezultati dosadašnjih istraživanja govore da postoji veza između ekonomskog razvoja, rodne ravnopravnosti i ruralnog razvoja pojedinih područja. Žensko agrarno preduzetništvo oslonjeno na multifunkcionalnu poljoprivredu i agrobiznis može stvoriti povoljnu poslovnu klimu u celom regionu. Uporednom analizom ženskog agrarnog preduzetništva nekih naseljenih mesta sa severa i juga Srbije dobijaju se podaci koji mogu pomoći u kreiranju pojedinačnih, regionalnih razvojnih politika. Iskustvo, stavovi, sugestije i preporuke od strane anketiranih preduzetnica pružaju retko dostupne informacije ženama na selu koje razmišljaju o pokretanju sopstvenog biznisa.
\end{abstract}

Ključne reči: žensko agrarnopreduzetništvo, rodna ravnopravnost, agrobiznis, selo, ekonomski razvoj, ruralni razvoj

5 Docent, dr Maksimović Goran, Univerzitet u Prištini, Poljoprivredni fakultet, 38219 Lešak, Telefon: +381 2888 261, E-mail: goran.maksimovic@pr.ac.rs

6 Master Otović Slavica, menadžer za odnose s javnošću, Opšta bolnica Vrbas, Ulica Dr M. Čekića br. 4, 21460 Vrbas, mt: +381 648023 215, E-mail: slavicaotovic1@gmail.com

7 Master Demirović Dunja, student doktorant, Univerzizet u Novom Sadu, Prirodno-matematički fakultet, Departman za geografiju, turizam i hotelijerstvo, Trg Dositeja Obradovića br. 3, Novi Sad, Telefon: +381 642686 290, E-mail: demirovic.dunja2@gmail.com

8 BA Vermezović Tatjana, master student, Univerzitet u Novom Sadu, Filozofski fakultet, Odsek za psihologiju, Novi Sad, tel: +381 63521 715, E-mail: tatjana.vermezovic@gmail.com 